\title{
Pengaruh Pendapatan Kamar dan Biaya Komisi Penjualan Terhadap Average Room Rate Hotel di Daerah Denpasar
}

\author{
Putu Sanjaya Budi Darma ${ }^{1}$ \\ Ni Gusti Putu Wirawati \\ ${ }^{1,2}$ Fakultas Ekonomi dan Bisnis Universitas Udayana (Unud), Bali, Indonesia \\ e-mail: budidarmasanjaya@gmail.com
}

\begin{abstract}
ABSTRAK
Tujuan dari penelitian ini adalah untuk mengetahui pengaruh pendapatan kamar dan biaya komisi penjualan terhadap average room rate hotel di daerah Denpasar. Jumlah sampel penelitian ini adalah 80 Hotel yang terdaftar di hotel asosiasi Denpasar. Pengumpulan data dilakukan dengan metode observasi non partisipan. Berdasarkan hasil analisis ditemukan bahwa pendapatan kamar dan biaya komisi penjualan secara simultan berpengaruh signifikan terhadap AAR.. Pendapatan kamar secara parsial berpengaruh signifikan terhadap AAR. Hal ini menunjukan bahwa pendapatan kamar yang memuaskan akan memberikan nilai average room rate yang bagus. Komisi penjualan secara parsial berpengaruh signifikan terhadap Average room rate. Hal ini menunjukan bahwa komisi penjualan dari pendapatan kamar yang dihasilkan yang diberikan kepada travel agent akan semakin bagus produktivitas atas AAR hotel yang di berikan.
\end{abstract}

Kata Kunci: Pendapatan kamar, biaya komisi penjualan, average room rate

\begin{abstract}
The purpose of this study was to determine the effect of room income and sales commission costs on the average room rate of hotels in the Denpasar area .The number of samples of this study were 80 hotels registered in the association hotel Denpasar. Data collection is done by non-participant observation method. Based on the results of the analysis it was found that room income and sales commission costs simultaneously had a significant effect on AAR. Room income partially has a significant effect on AAR. This shows that satisfying a room will provide a good average room rate. Sales commissions partially have a significant effect on AAR This shows that the sales commission from the room revenue generated given to travel agents will be better productivity for the average hotel rate hotel that is given.
\end{abstract}

Keywords: Room income, sales commission costs, average room rate

\section{PENDAHULUAN}

Bali merupakan sebuah pulau yang terletak di negara kepulauan Indonesia, dimana Bali sendiri sudah sangat terkenal akan objek wisatanya. Budaya yang berbeda dan keindahan alam dari pulau Bali, menjadikan Bali menjadi magnet bagi wisatawan dari mancanegara maupun domestik. Mayoritas wisata di Bali adalah wisata yang mengedepankan sebuah wisata panorama, kultural hingga berbagai wisata penunjang lainnya seperti wisata kuliner, tren pakaian dan wisata 
kebugaran. Salah satu wisata panorama yang terkenal di Bali adalah pantai, seperti Pantai Kuta, Pantai Sanur, Pantai Nusa Dua dan lain-lain.

Selain pantai, panorama alam seperti pegunungan dapat ditemukan di daerah Denpasar dan kintamani hingga berbagai macam objek kultural seperti Pura, Museum dan lainnya. Hadirnya beragam tujuan wisata di Bali, memunculkan beragam sarana pendukung dari industri pariwisata, contohnya hotel, restoran, spa, penyewaan kendaraan, jasa tur, wahana air, diskotik dan sebagainya. Namun dari seluruh sarana pendukung tema bisnis pariwisata terutama di Bali, adalah industri perhotelan.

Hotel merupakan salah satu jenis akomodasi yang sangat dikenal oleh masyarakat. Usaha perhotelan sekarang ini sudah merupakan suatu industri hotel yang memerlukan sumber dana dan sumber daya manusia dalam jumlah besar, dengan resiko kerugian atau keuntungan yang besar pula. Secara umum, produk yang dijual oleh pihak manajemen hotel terdiri dari dua produk yaitu produk nyata (tangible product) seperti kamar hotel, restoran, spa, dan berbagai fasilitas hotel lainnya dan produk tidak nyata (intangible product) seperti kenyamanan, layanan, suasana dan lain sebagainya.

Menurut(Sihite, 2010) secara garis besar penggolongan hotel berdasarkan lokasi, terdapat dua jenis hotel yaitu city hotel yang terletak di pusat kota, dan resort hotel yang terletak di suatu daerah tertentu yang lebih mengedepankan pemandangan dan suasana yang nyaman. Baik city hotel maupun resort hotel memiliki pangsa pasar masing-masing yang sama-sama diminati oleh wisatawan yang berkunjung ke Bali. Hal tersebut menyesuaikan dengan kemampuan para 
wisatawan dan selera akan akomodasi yang diinginkan oleh wisatawan. Namun pada umumnya, akomodasi city hotel lebih terjangkau dibandingkan resort hotel. Hal tersebut disebabkan karena resort hotel menawarkan kenyamanan dan suasana yang lebih spesial karena para wisatawan dimanjakan dengan arsitektur bangunan hingga pemandangan yang tersedia di resort hotel.

Denpasar memiliki daya tarik yang kuat bagi para wisatawan mancanegara, ditunjang dengan beberapa pantai terkenal seperti Pantai Sanur yang diminati oleh wisatawan dengan panorama matahari terbitnya. Selanjutnya juga terdapat beberapa tempat bersejarah seperti musem Le Mayuer dan museum Bali serta panggung kesenian Art Centre yang menarik minat wisatawan. Untuk mengakomodasi wisatawan yang tertarik berkunjung ke Denpasar, terdapat hotelhotel di daerah Denpasar. Hotel-hotel di daerah Denpasar memiliki beragam kelas hotel, dimulai dari guest house, private villa hingga hotel berbintang. Hotel tersebut memiliki beberapa fasilitas dan pelayanan yang unik untuk setiap tamu yang menginap. Beberapa hotel menyediakan pemandangan hutan, sungai dan hamparan sawah di area hotel.

Fenomena yang terjadi pada hotel di Denpasar perihal pendapatan kamar di Denpasar adalah meningkatnya pendapatan kamar hotel, maka dapat menurunkan minat wisatawan berkunjung ke hotel tersebut. Penurunan minat wisatawan tersebut disebabkan oleh penawaran harga yang lebih murah dari hotel lain di daerah Denpasar dengan fasilitas yang serupa, tidak adanya peningkatan pelayanan lebih terhadap tamu, dan makanan maupun minuman yang disajikan belum sesuai standar tamu. Wisatawan dapat memiliki pilihan yang serupa dengan 
harga yang lebih murah terutama semenjak adanya situs online travel agent yang secara transparan menampilkan harga dari hotel - hotel yang terdaftar.

Pendapatan kamar dapat dicapai dengan melakukan penjualan ke beberapa travel agent yang bekerja sama dengan pihak hotel. Travel agent tersebut menjual harga kamar yang lebih rendah dibandingkan jika tamu datang langsung ke hotel. Sejak area internet telah menjadi bagian dari gaya hidup kebanyakan orang, maka bermunculanlah Online Travel Agent.

Sistem kerjasama yang diberlakukan oleh Online Travel Agent adalah sistem commission based. Sistem ini akan membuat pihak hotel bebas untuk menjual harga kamar hotel sesuai keperluan dari hotel, dan pihak Online Travel Agent akan mengenakan komisi kepada setiap transaksi pembelian yang berhasil dilakukan. Besar persentase komisi tersebut bergantung pada kebijakan masingmasing Online Travel Agent.

Isu yang terjadi adalah jika hotel yang bekerja sama dengan online travel agent, hotel harus sepakat dengan besaran persentase komisi yang dibebankan kepada hotel setiap pemesanan hotel terjadi. Biaya komisi tersebut akan meningkat seiring dengan peningkatan pemesanan kamar hotel yang melalui situs online travel agent seperti booking.com, Traveloka dan Tiket.com. Meningkatnya biaya komisi akan berimplikasi terhadap peningkatan beban operasional hotel tersebut.

Hotel memiliki indikator dalam penjualan kamar yaitu average room rate, dimana dalam artian harga jual rata-rata kamar hotel tersebut. Average room rate menjadi salah satu indikator manajemen dalam melihat pergerakan bisnis hotel 
mereka. Jika average room rate dari sebuah hotel kecil, besar kemungkinan hotel tersebut menjual harga dibawah dari harga awal yang ditetapkan oleh kesepakatan manajemen (Adekunle, 2014).

Motivasi dalam penelitian ini adalah ketertarikan antara isu dan fenomena mengenai perkembangan hotel di Denpasar yang dewasa ini mendapatkan banyak pemesanan kamar dari situs online travel agent. Jika hotel tersebut terkenal dan mendapatkan banyak pemesanan dari online travel agent, maka hotel tersebut memiliki potensi pembayaran komisi yang lebih besar dibandingkan hotel lain di Denpasar.

Kata hotel berasal dari bahasa Perancis "hostel" yang berarti rumah penginapan bagi orang - orang yang sedang mengadakan perjalanan atau bepergian. Perhotelan adalah bidang usaha yang berkembang seiring dengan kemajuan sektor pariwisata. Usaha hotel memiliki cirri - ciri khusus yaitu perpaduan antara usaha menjual produk nyata hotel seperti kamar, makanan, dan minuman dengan menjual jasa pelayanan seperti keramahan, sopan santun, kecekatan, kemudahan dan lain - lain. Untuk memperjelas mengenai usaha perhotelan, berikut ini beberapa pengertian dari hotel.

Menurut (Bagyono, 2013) menyatakan bahwa : "Dalam arti luas, hotel mungkin merujuk pada segala jenis penginapan. Sedangkan dalam arti sempit, hotel adalah sebuah bangunan yang dibangun khusus untuk menyediakan penginapan bagi pada pejalan, dengan pelayanan makanan dan minuman". Peraturan Pemerintah Republik Indonesia No. 67 Tahun 1996 menyatakan bahwa : "Pelayanan pokok usaha hotel yang harus disediakan sekurang - kurangnya 
harus meliputi penyediaan kamar tempat menginap, penyediaan tempat dan pelayanan makan dan minum, penyediaan pelayanan pencucian pakaian/binatu dan penyediaan fasilitas lainnya. Peraturan Pemerintah tersebut secara implisist memberikan definisi mengenai kata hotel".

Berdasarkan beberapa definisi di atas maka dapat disimpulkan bahwa hotel merupakan suatu badan usaha yang bergerak dibidang jasa akomodasi yang dikelola secara komersial yang dilengkapi dengan penyediaan makanan dan minuman serta fasilitas lainnya.

Perwakilan adalah biro perjalanan umum, agen perjalanan, badan usaha lainnya atau perorangan yang ditunjuk oleh suatu biro perjalanan umum yang berkedudukan di wilayah lain untuk melakukan kegiatan yang diwakilkan, baik secara tetap maupun sementara. Menurut (Vallen, 2015)“Biro perjalanan (Travel) adalah suatu perusahaan yang memperoleh pendapatan dan keuntungan dengan menawarkan dan menjual produk serta jasa-jasa pelayanan yang diberikannya kepada pelanggannya.”.

Sedangkan menurut Menurut (Brian, 2014) "Biro perjalanan (Travel) adalah sebuah perusahaan yang menjual rancangan perjalanan secara langsung pada masyarakat dan lebih khusus lagi menjual ransportasi udara, darat, laut; akomodasi penginapan; pelayaran wisata; wisata paket; asuransi perjalanan; dan produk lainnya yang berhubungan".

Online Travel Agent adalah salah satu jenis dari Travel Agent yang melakukan seluruh kegiatannya melalui online (Campbell, 2015). Jenis Travel Agent ini menyediakan layanan reservasi online (online reservation) merupakan 
sarana yang dibutuhkan seseorang dalam melakukan perjalanan. Tugas Online Travel Agent adalah menjadi perantara yang dipercaya dan konsultan bagi perusahaan akomodasi dan maskapai penerbangan dalam promosi secara online dan meningkatkan kunjungan tamu (Yee, 2013)

Online Travel Agent juga memberikan kemudahan dari segi reservasi kamar dengan fasilitas online reservation form dilengkapi room availability yang mudah dipahami dan langsung diproses melalui situs tersebut ke hotel atau restoran yang dituju. Secara umum, pihak hotel yang bekerjasama dengan perusahaan Online Travel Agent melakukan pembayaran perbulan sesuai komisi yang disepakati dengan perhitungan persentase dengan harga kamar per malam (Christanto, 2014).

Menurut (Danny, 2013) "Insentif adalah sesuatu yang mendorong atau yang mempunyai kecenderungan terhadap seseoreng untuk melakukan tindakan.” (Dunette, 2016) menerangkan kegunaan insentif yaitu "Guna lebih mendorong produktivitas kerja yang lebih tinggi, banyak organisasi yang menganut sistem insentif sebagai bagian dari sistem imbalan yang berlaku bagi para karyawan organisasi."

Sedangkan menurut (Fallon, 2015) mengatakan : "Istilah sistem insentif mempunyai pengertian yang terbatas, karena tidak mencakup banyak jenis perangsang yang ditawarkan kepada para karyawan untuk melaksanakan kerja sesuai atau lebih tinggi dari standar-standar yang telah ditetapkan. Sebagai contoh, sistem ini tidak meliputi pembayaran upah kerja lembur, upah untuk waktu tidak bekerja, atau upah diferensial berdasarkan shift. Begitu juga, istilah itu pada 
Putu Sanjaya Budi Darma dan Ni Gusti Putu Wirawati. Pengaruh ...

umumnya digunakan dengan tidak mencakup pembayaran premi untuk pelaksanaan tugas-tugas yang berbahaya."

Terdapat dua tipe komisi penjualan penjualan yang dapat digunakan pada easy accounting system yakni, Persentase dan Jumlah Tetap. Perhitungan komisi dengan menggunakan persentase adalah perhitungan secara otomatis yang akan dikalikan dengan persentase tertentu yang akan dikalikan dengan dasar perhitungan komisi. Perhitungan komisi dengan jumlah tetap adalah perhitungan komisi dengan jumlah komisi yang telah ditetapkan, nilai yang ditetapkan tersebut tidak akan berubah, jadi komisi yang didapat akan tetap sama meskipun nilai penjualan berbeda.

Pengertian average room rate usaha menurut (Gordon, 2016) adalah “Average room rate harga rata-rata penjualan kamar yang diperoleh kegiatan utama perusahaan perhotelan yaitu penjualan kamar". Sedangkan menurut (Gehee, 2016) "Average room rate adalah hasil akhir dari pendapatan penjualan kamar secara rata - rata dari periode tertentu". Selain itu menurut (Wild, 2013:407) "Average room rate merupakan selisih pendapatan dan keuntungan setelah dikurangi beban dan kerugian. Average room rate merupakan salah satu pengukur aktivitas operasi dan dihitung berdasarkan atas dasar akuntansi akrual".

Berdasarkan definisi diatas maka dapat ditarik kesimpulan bahwa Average room rate adalah harga rata-rata penjualan kamar yang diperoleh dari penjualan kamar hotel tersebut. Informasi average room rate diperlukan untuk mengetahui kontribusi Pendapatan kamar dalam menutupi biaya hotel tersebut. 
Penjelasan konsep senjangan anggaran dapat dimulai dari pendekatan teori keagenan, sehingga teori keagenan dijadikan acuan dalam penelitian ini. Teori keagenan menjelaskan mengenai kontrak yang terjadi antara prinsipal dengan agen serta menunjuk orang lain sebagai agen dalam melaksanakan jasa untuk pengambilan suatu keputusan (Jensen \& Meckling, 1976). Terdapat beberapa asumsi mengenai teori keagenan yaitu asumsi yang membahas tentang konflik antaranggota organisasi, keorganisasian, efisiensi dan asimetri informasi antara prinsipal dan agen. Dilihat dari sudut pandang teori keagenan, prinsipal membawahi agen untuk melaksanakan kinerja yang efisien. Agen dan prinsipal diasumsikan termotivasi oleh kepentingan sendiri dan seringkali kepentingan antara keduanya berbenturan. Teori keagenan memberikan dasar untuk memahami mengapa seorang individu dapat termotivasi untuk bertindak dengan cara yang menciptakan senjangan anggaran (Harvey, 2015). Praktik senjangan anggaran dalam perspektif agency theory dipengaruhi oleh adanya konflik kepentingan antara agen dengan prinsipal yang timbul ketika setiap pihak berusaha untuk mencapai atau mempertahankan tingkat kemakmuran yang dikehendakinya. Namun, ketika prinsipal dan agen memiliki kesamaan kepentingan maka kepentingan bersama dijadikan dasar dari pengambilan keputusan yang mana hal ini sejalan dengan teori stewardship (Donaldson dan Davis, 1989).

Secara umun hotel diartikan sebagai suatu akomodasi yang dikelola secara komersial yang menyediakan jasa pelayanan, penginapan, makan, minum yang disediakan bagi para tamu. Menurut (Sihite, 2010) hotel dibagi menjadi beberapa jenis yaitu sebagai berikut: 1) Transient Hotel, yaitu hotel yang letak dan 
lokasinya di tengah kota dengan jenis tamu yang menginap sebagian besar adalah untuk urusan bisnis dan turis. 2) Residential Hotel, yaitu hotel yang pada dasarnya merupakan rumah - rumah berbentuk apartemen dengan kamar - kamar yang disewakan secara bulanan atau tahunan, juga menyediakan kemudahan kemudahan seperti layaknya hotel seperti restoran, pelayanan makanan yang diantar ke kamar, dan pelayanan kebersihan kamar; 3) Resort Hotel, yaitu hotel pada umumnya yang berlokasi di tempat - tempat wisata untuk melayani konsumen yang sedang berekreasi. 4) Motel/ Motor Hotel, yaitu hotel yang mempunyai lokasi sepanjang jalan raya yang menghubungkan satu kota besar dengan kota besar lainnya. Hotel jenis ini menyediakan parkir khusus seatap dengan kamar hotel.

Pandangan akuntansi memiliki keanekaragaman dalam memberikan pengertian pendapatan. Ilmu akuntansi melihat pendapatan sebagai sesuatu yang spesifik dalam pengertian yang lebih mendalam dan lebih terarah. Pada dasarnya konsep pendapatan menurut ilmu akuntansi dapat ditelusuri dari dua sudut pandang, yaitu: 1) Pandangan yang menekankan pada pertumbuhan atau peningkatan jumlah aktiva yang timbul sebagai hasil dari kegiatan operasional perusahaan pendekatan yang memusatkan perhatian kepada arus masuk atau inflow. Menurut SFAC (Statement of Financial Accounting Concepts) No.6, menekankan pengertian pendapatan pada arus masuk atau peningkatanpeningkatan lainnya atas aktiva suatu entitas atau penyelesaian kewajibankewajibannya atau kombinasi keduanya yang berasal dari pengiriman atau produksi barang, penyelenggara jasa, pelaksanaan aktivitas-aktivitas lainnya yang 
merupakan kegiatan operasi utama entitas tersebut yang berlangsung terusmenerus. 2) Pandangan yang menekankan kepada penciptaan barang dan jasa oleh perusahaan serta penyerahan barang dan jasa atau outflow.

Menurut PSAK No.23 paragraf 06 Ikatan Akuntan Indonesia (2010;23.2), menyatakan bahwa: "Pendapatan adalah arus kas masuk bruto dari manfaat ekonomi yang timbul dari aktivitas normal perusahaan selama suatu periode bila arus masuk tersebut mengakibatkan kenaikan ekuitas, yang tidak berasal dari kontribusi penanam modal".

Menurut Kieso, Warfield dan Weygantd (2011;955), menjelaskan definisi pendapatan adalah sebagai berikut: "Gross inflow ofeconomic benefits during the period arising in the ordinary activities of an entity when those inflows result in increases in equity, other than increases relating to contributions from equity participants". Dari keterangan di atas dapat disimpulkan bahwa pendapatan adalah arus masuk bruto dari manfaat ekonomi yang timbul dari aktivitas normal entitas selama suatu periode, jika arus masuk tersebut mengakibatkan kenaikan ekuitas yang tidak berasal dari kontribusi penanam modal.

Pendapatan kamar yang tinggi akan meningkatkan potensi average room rate yang tinggi dari hotel. Hal tersebut berdasarkan penelitian terdahulu oleh Dwi, Agustin pada tahun 2011 yang menyatakan bahwa harga pengaruh positif terhadap jumlah hunian kamar pada hotel Grand Aloha Lumajang Jawa Timur. Selain itu berdasarkan teori dari (Fallon, 2015) menyatakan bahwa average room rate hotel tersebut akan meningkat jika pihak hotel dapat menjaga harga jual kamar sesuai dengan kelas hotel tersebut. Jika terjadi perang harga antar sesama 
hotel yang menyebabkan pendapatan kamar menurun, maka nilai average room rate akan mengalami penuruan Berdasarkan hal tersebut dapat dijabarkan hipotesis pertama yaitu:

$\mathrm{H}_{1}$ : Pendapatan kamar berpengaruh positif terhadap average room rate hotel di Daerah Denpasar.

Biaya komisi penjualan dibebankan kepada hotel karena sebagai bentuk balas jasa kepada pihak online travel agent yang memasarkan hotel tersebut secara digital, hingga terjadinya pemesanan kamar hotel tersebut. Pemesanan kamar hotel melalui situs online travel agent akan dikenakan biaya komisi, jadi semakin tinggi penjualan melalui online travel agent semakin tinggi potensi average room rate hotel tersebut. Hal tersebut berdasarkan peneltian terdahulu oleh Yuwono, Indra. 2015 yang menyatakan bahwa pelaksanaan advertising berpengaruh terhadap peningkatan average room rate pada Hotel Kalpataru Kota Malang. Berdasarkan teori dari (Gehee, 2016) menyatakan komisi penjualan yang tinggi akan menambahkan beban kepada operasional hotel, dimana nilai beban tersebut dapat didistribusikan kepada nilai average room rate hotel tersebut. Berdasarkan hal tersebut dapat dijabarkan hipotesis kedua yaitu:

$\mathrm{H}_{2}$ : Biaya komisi penjualan berpengaruh positif terhadap average room rate Hotel di Daerah Denpasar.

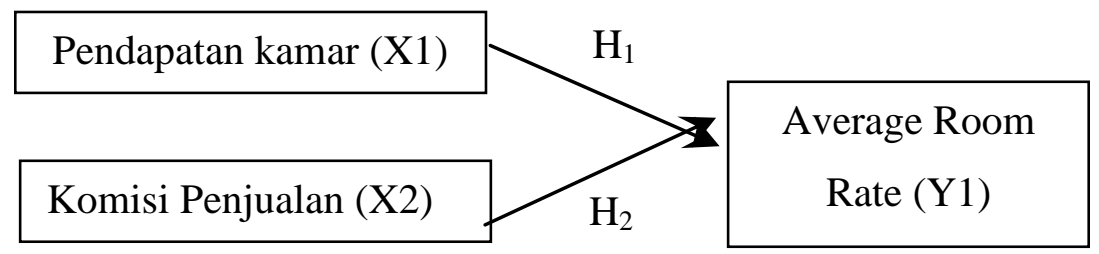

\section{Gambar 1. Kerangka Konseptual}

Sumber: Data diolah, 2018 


\section{METODE PENELITIAN}

Metode penelitian menggunakan metode kuantitatif yang meneliti pada populasi atau sampel tertentu, dengan menggunakan teknik pengambilan sampel secara acak dengan simple random sampling, pengumpulan data menggunakan instrumen penelitian, serta analisis data menggunakan uji regresi linier berganda, uji f dan uji t dengan tujuan menguji hipotesis yang telah ditetapkan serta mengkonfirmasi teori. Penelitian ini dilakukan agar dapat mengetahui pengaruh Pendapatan kamar dan biaya komisi penjualan terhadap average room ratehotel di daerah Denpasar.Desain penelitian ini digambarkan sebagai berikut:

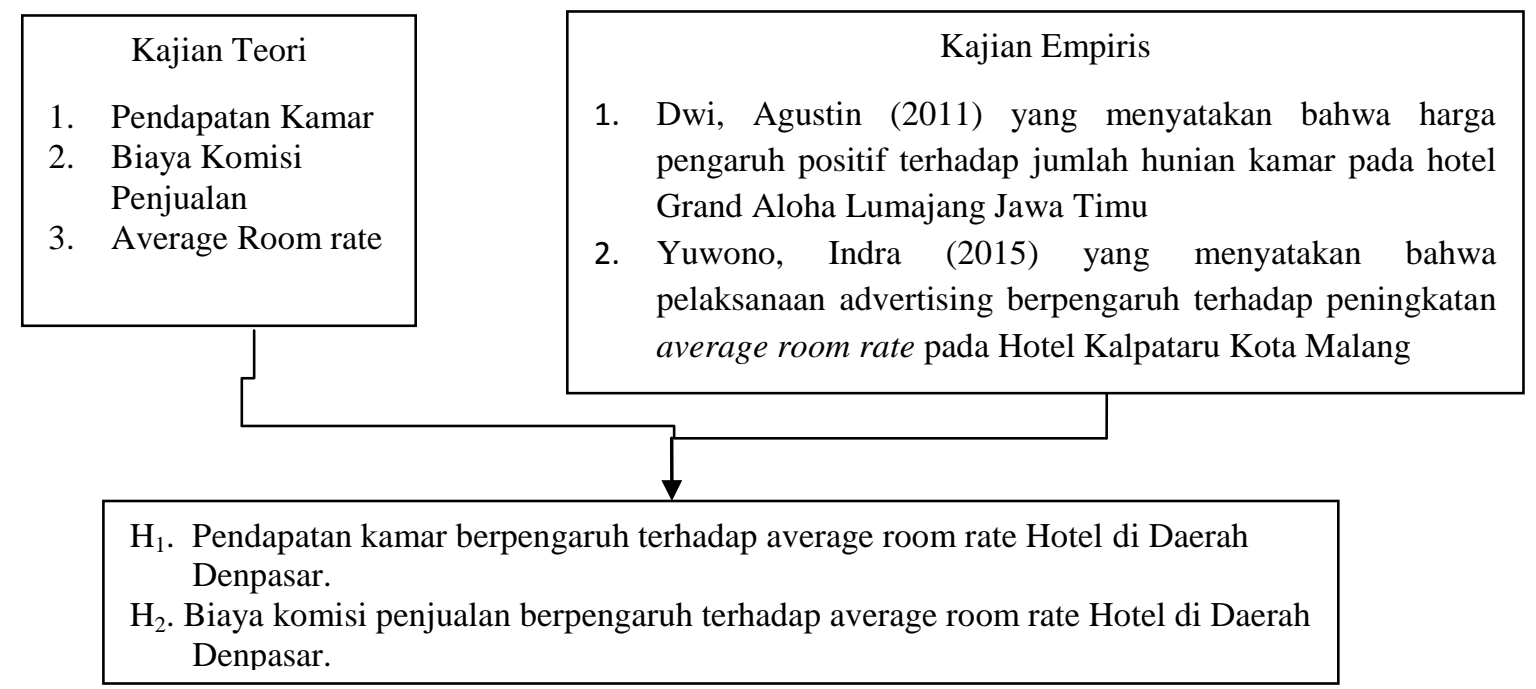

Sumber: Data diolah, 2018

\section{Gambar 2. Desain Penelitian}

Tempat penelitian ini dilakukan di hotel yang terdaftar di booking.com periode 2017 dengan mengakses www.booking.com. Objek penelitian ini adalah pengaruh Pendapatan kamar dan biaya komisi penjualan terhadap average room rate hotel di daerah Denpasar. Populasi dalam penelitian ini adalah hotel-hotel di daerah Denpasar yang tergabung dalam organisasi Hotel Di Daerah Denpasar sebanyak 167 hotel yang aktif di asosiasi. 
Putu Sanjaya Budi Darma dan Ni Gusti Putu Wirawati. Pengaruh ...

Memberi batasan dan untuk lebih memperjelas ruang lingkup permasalahan maka berikut ini akan diuraikan secara singkat variabel - variabel yang terdapat dalam permasalahan yang akan dibahas, yaitu : Pendapatan kamar, pada siklus penjualan akan melibatkan akun piutang usaha (city ledger, guest ledger, credit card), akun kas dan setara kas, akun penjualan, akun hutang pajak PHR (Government Tax) dan memungut uang jasa pelayanan kepada para konsumen atas nama karyawan. Biaya komisi penjualan besarnya komisi dihitung berdasarkan harga barang dan jasa yang terjual. Berikut adalah perhitungan komisi penjualan atas penjualan kamar :

Biaya komisi $=$ Persentase Komisi $\mathrm{x}$ Total Pendapatan kamar

ARR merupakan indikator yang digunakan untuk mengetahui "rata-rata harga kamar" yang terjual pada kurun waktu tertentu dengan menghitung ratarata harga kamar berdasarkan jumlah kamar yang dihuni oleh tamu. (www.gondonesia.com)

ARR $=$ Total Pendapatan Kamar : Total Kamar Terjual

Teknik analisis regresi linier berganda digunakan dalam penelitian ini. Persamaan umumnya adalah:

$$
Y=a+b_{1} X_{1}+b_{2} X_{2}+e
$$

Keterangan :

$\mathrm{Y}=$ Average Room Rate

$\mathrm{X}_{1} \quad=$ Pendapatan Kamar

$\mathrm{X}_{2} \quad=$ Biaya Komisi Penjualan

$\mathrm{a} \quad=$ Konstanta

$\mathrm{b}_{1}=\mathrm{b}_{2}=$ arah garis regresi yang menyatakan perubahan nilai Y akibat perubahan 1 unit $X$ (koefisien regresi masing - masing $X_{i}$ )

e $\quad=$ Variabel Pengganggu (Residual Error) 


\section{HASIL DAN PEMBAHASAN}

Penelitian ini dilakukan pada hotel yang ada di daerah Denpasar.Jumlah hotel pada periode ini sebanyak 80 Hotel, yaitu :Kesari Hotel Villa and Restaurant, Leha Leha Villa,Lembayung Sari hotel, Mahagiri Villas Sanur, Mai Mesaree Villa, Akana Hotel Sanur, Fortuna Hotel, Maya Sanur Resort \& Spa, Natah Bale Villas, Ninja Suite Villa, Ocean hotel Villa, Palma Bed And Breakfast, Pelangi Bali hotel, Pollok and Lemayeur Beach Front Hotel, Taksu Sanur Hotel, Pondok Taman 828 Guest hotel, Princess Keisha Hotel Denpasar, Butterfly Bali, Puri Saron Hotel Denpasar, Puri Yuma Hotel, Quest Hotel Denpasar, Safira Residence, Sanur Paradise Plaza Hotel, Segara Village Sanur, SooBali Halemahina, SooBali Uma Joglo, Sugiras Living Guest hotel, Suwardika hotel \& Dormitory, The Bagus Villa, De Cubu, The Paica Hotel, The Palm Suite Villa \& Spa, The Pavilions Bali, The Yuma Bali Hotel, The Zen Villas, Uma De Villa, Villa Alam Biru Sindu, Villa Denira, Villa Dewandara, Villa Gunung Catur, Praja Hotel, B Hotel Bali \& Spa, Ibis Style Bali \& Spa, Pop! Hotel Denpasar, Inna Bali Heritage Hotel, Bali Dream Costel, The Rani Garden Bed \& Breakfast, Bali True Living, Neo Hotel Denpasar, Golden Tulip Denpasar, Harris Hotel Denpasar, The Banyumas Villa, Alam Putri Resort, Akila, Starfish, Paras Paros Marina Lodge, Taman Ayu Town House, Pop! Hotel Teuku Umar, Sugiras Living, Kori Bata Hotel, Amaris Teuku Umar, Art Hotel Sanur, Hotel Oranjje, Sylvia Bali Suite, Mahajaya Hotel, Mars City Hotel, Dee Mansion, Catur Adi Putra Hotel, Ganga Hotel, Choice Stay Hotel, Dekrisna, Cempaka Living, Griya Tunjung Sari, Anantaya, The VinHill, Santosa 
City, Adikara Renon, The vasini, Alba Sanur, dan The Alantara Sanur.Hotel memiliki katagori kamar meliputi :

Standard Room atau kamar standard merupakan sebutan kamar paling murah di sebuah hotel dan biasanya merupakan istilah di hotel-hotel Amerika. Tetapi berbeda dari kamar single (single room), kamar standard untuk setiap hotel itu berbeda-beda. Terkadang memiliki satu ranjang king-size, double dengan 2 ranjang queen-size, atau bahkan memang hanya satu ranjang seperti single room.Kamar standard memiliki fasilitas yang paling dasar, biasanya sebuah televisi, pembuat kopi, telepon, meja, kloset dan kamar mandi. Fasilitas tambahannya juga tergantung dari hotel tersebut. Tentunya hotel bintang 2 dengan hotel bintang 5 memiliki fasilitas standard yang berbeda. Tapi memang standard room merupakan kamar paling murah dari suatu hotel.

Biasanya kamar tipe superior ini memiliki definisi yang berbeda-beda di setiap hotel. Terkadang merupakan kamar standard dengan ukuran dan fasiltias yang lebih. Atau juga terkadang mungkin merujuk ke kamar khusus dengan pemandangan atau lokasi yang lebih baik. Biasanya dikenal juga dengan namapremium room.Sederhanya adalah merupakan kamar yang dilihat hotel lebih baik daripada standard room. Cara terbaik tentunya lebih baik Anda menanyakan terlebih dahulu fasilitas kamar superior di hotel terkait.

Hotel mempunyai struktur organisasi yang digunakan adalah struktur garis, dimana sekelompok orang atau lebih yang secara formal dipersatukan dalam suatu kerja sama untuk mencapai tujuan yang telah ditetapkan. Adapun struktur organisasi hotel digambarkan sebagai berikut: 


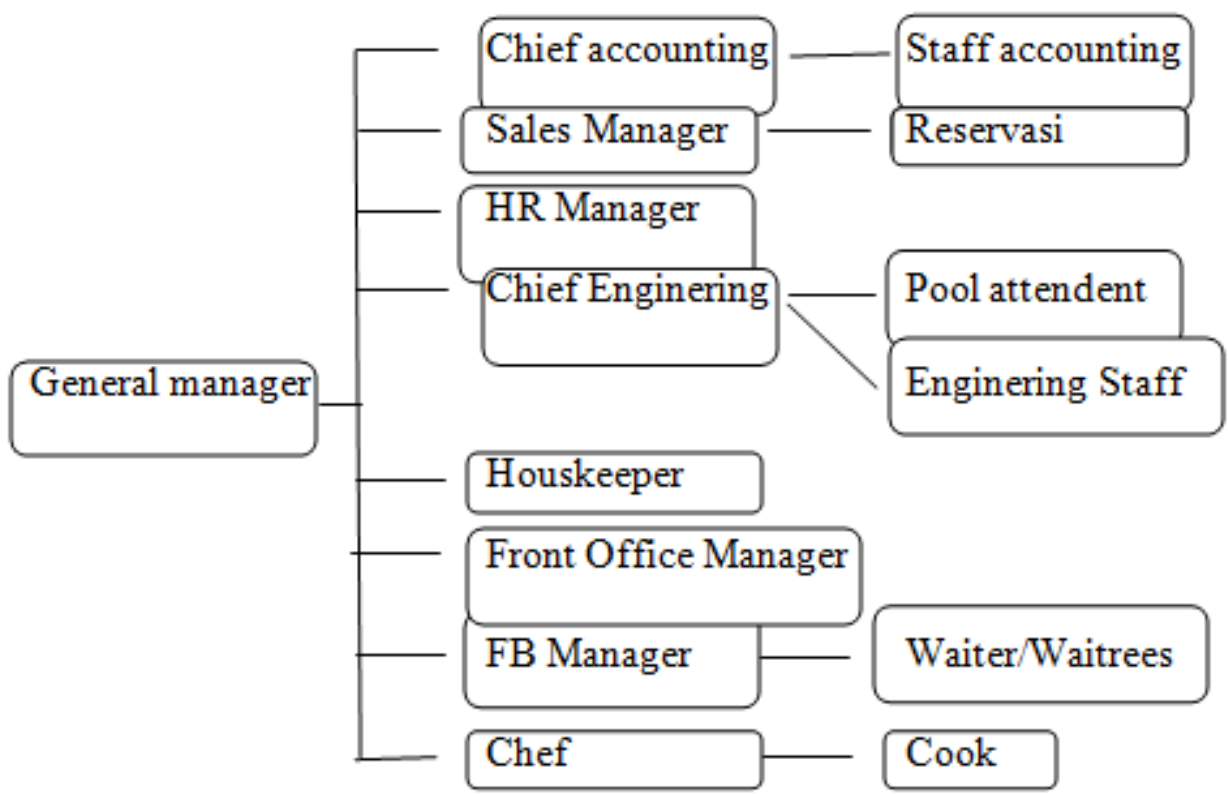

Gambar 3. Struktur Organisasi Hotel

Sumber: Data diolah, 2018

Tabel 1. dapat dilihat hasil uji deskriptif. Nilai minimum pendapatan kamar sebesar 10331.00 dimiliki oleh B Hotel Bali \& Spa dan nilai maksimum sebesar 88891.00 dimiliki oleh Mai Mesaree Villas. Nilai minimum komisi penjualan kamar sebesar 1114.00 dimiliki oleh Taman Ayu Town House dan nilai maksimum sebesar 8897.00 dimiliki oleh Ninja Suite Villa. Nilai minimum average room rate sebesar 413.00 dimiliki oleh Dee Mansion dan nilai maksimum sebesar 2361.00 dimiliki oleh Ninja Suite Villa.

Tabel 1.

Analisis Deskriptif

\begin{tabular}{|c|c|c|c|c|c|}
\hline & $\mathrm{N}$ & Minimum & Maximum & Mean & Std. Deviation \\
\hline Pendapatan Kamar & 80 & 10331.00 & 88891.00 & 23444.6875 & 15048.69254 \\
\hline Komisi Penjualan Kamar & 80 & 1114.00 & 8897.00 & 4880.6500 & 2014.02679 \\
\hline Average Room Rate & 80 & 413.00 & 2361.00 & 1107.5375 & 511.82080 \\
\hline Valid N (listwise) & 80 & & & & \\
\hline
\end{tabular}

Sumber : Data diolah 2018 
Uji normalitas model bertujuan untuk menguji apakah dalam model regresi, variabel pengganggu atau residual memiliki distribusi normal. Uji normalitas dilakukan dengan menggunakan uji statistikKolmogorov-Smirnof (K-S). Model regresi yang baik adalah mempunyai distribusi data normal atau mendekati normal.

Tabel 2.

Hasil Uji Normalitas

\begin{tabular}{llr}
\hline & & Unstandardized Residual \\
\hline $\mathrm{N}$ & & 80 \\
Normal Parameters & Mean & .0000000 \\
& Std. Deviation & 389.57551297 \\
Most Extreme Differences & Absolute & .075 \\
& Positive & .075 \\
Kolmogorov-Smirnov Z & Negative & .058 \\
Asymp. Sig. (2-tailed) & & .672 \\
Sumber: Data diolah, 2018 & & .757 \\
\hline
\end{tabular}

Berdasarkan Tabel 2 hasil pengujian normalitas residual sudah berdistribusi normal, yang ditunjukan dari nilai signifikansi Kolmogorov-Smirnof sebesar 0.757 lebih besar dari 0.05 . hal ini berarti data residual berdistribusi normal.

Uji Multikolinearitas bertujuan untuk menguji apakah ada model regresi ditemukan adanya korelasi antara variabel bebas. Model regresi yang baik seharusnya tidak terjadi korelasi diantara variabel bebas atau bebas dari gejala multikolinier. Untuk mendeteksi ada atau tidaknya korelasi antar sesama variabel bebas dapat dilihat dari nilai tolerance dan nilai variance inflation factor.

Nilai tolerance dari pendapatan kamar adalah 0.966, dan komisi penjualan kamar adalah 0.966 yang mana hasil nilai tolerance diatas 0.10 . Hal ini berarti tidak ada korelasi antar variabel bebas. Hasil perhitungan variance inflation factor (VIF) dari pendapatan kamar adalah 1.035 dan komisi penjualan kamar adalah 1.035 yang menunjukan bahwa nilai VIF dibawah 10 yang juga berarti tidak ada 
kolerasi dari variabel bebas. Uji Heteroskedastisitas bertujuan menguji apakah model regresi terjadi ketidaksamaan varians dari residual satu pengamatan ke pengamatan lain. Model regresi yang baik adalah yang tidak mengandung gejala heteroskedastisitas / mempunyai varian yang homogen.

Tabel 2.

Uji Heteroskedastisitas

\begin{tabular}{llrl}
\hline & \multicolumn{1}{c}{ Model } & Sig. & \multicolumn{1}{c}{ Keterangan } \\
\hline & (Constant) & .223 & \\
1 & Pendapatan Kamar & .151 & Bebas Heteroskedastisitas \\
& Komisi Penjualan & .057 & Bebas Heteroskedastisitas \\
\multicolumn{2}{l}{ Kamar } & & \\
\hline \multicolumn{2}{l}{ Sumber $:$ Data diolah 2018} &
\end{tabular}

Sumber: Data diolah, 2018

Berdasarkan tabel 2 terlihat bahwa signifikansi dari variabel pendapatan kamar sebesar 0.151 dan Komisi penjualan kamar 0.057 menunjukan nilai signifikansi lebih besar dari 0.05 yang artinya tidak ada pengaruh variabel bebas pendapatan kamar dan komisi penjualan kamar terhadap absolut residual, sehingga layak digunakan untuk memprediksi karena tidak mengandung gejala Heteroskedastisitas.

Uji Autokorelasi bertujuan untuk melacak adanya korelasi auto atau pengaruh data dari pengamatan sebelumnya. Jika dalam suatu model regresi mengandung gejala autokorelasi, maka prediksi yang dilakukan dengan model tersebut akan tidak baik (bias), atau akan memberikan hasil prediksi yang menyimpang. Untuk mendeteksiterjadinya autokorelasi dalam penelitian ini dilakukan uji Durbin-Watson dengan melihat korelasinya. Uji Durbin-Watson dihitung berdasarkan jumlah selisih kuadrat nilai taksiran faktor gangguan yang berurutan. 
Nilai Durbin-Watson sebesar 2.037 dengan level signiifikan 5\%, untuk n = 80 dengan jumlah variabel bebas ( $\mathrm{k}$ ) sebanyak 2 , dL 1.5859 dan dU $=1.6882$. Hal ini menunjukkan bahwa dU $<\mathrm{d}<(4-\mathrm{dU})$ yaitu $1.6882<2.037<2.3118$, dengan demikian statistik berada pada daerah tidak ada autokorelasi. Hasil SPSS dari analisis regresi linier berganda dapat dilihat pada tabel 3 dibawah ini:

Tabel 3.

Analisis Regresi Linier Berganda

\begin{tabular}{|c|c|c|c|c|c|c|}
\hline \multirow[t]{3}{*}{ Model } & & \multirow{2}{*}{\multicolumn{2}{|c|}{$\begin{array}{l}\text { Unstandardized } \\
\text { Coefficients }\end{array}$}} & \multirow{3}{*}{$\begin{array}{c}\text { Standardized } \\
\text { Coefficients } \\
\text { Beta }\end{array}$} & \multirow[t]{3}{*}{$\mathrm{t}$} & \multirow[t]{3}{*}{ Sig. } \\
\hline & & & & & & \\
\hline & & B & $\begin{array}{l}\text { Std. } \\
\text { Error }\end{array}$ & & & \\
\hline \multirow{3}{*}{1} & (Constant) & 220.925 & 126.624 & & 1.745 & .085 \\
\hline & $\mathrm{X} 1$ & .009 & .003 & .253 & 2.862 & .005 \\
\hline & $\mathrm{X} 2$ & .140 & .022 & .552 & 6.259 & .000 \\
\hline
\end{tabular}

Sumber: Data diolah, 2018

Berdasarkan tabel 4 diperoleh persamaan regresi sebagai berikut :

$\mathrm{Y}=220.925+0.009 \mathrm{X} 1$ (pendapatan kamar) $+0.140 \mathrm{X} 2$ (komisi penjualan kamar)

Nilai koefisien regresi variabel pendapatan kamar (X1) sebesar 0.009 nilai yang positif menunjukan adanya hubungan searah antara average room rate dengan pendapatan kamar, jika pendapatan kamar meningkat sebesar satu satuan sementara variabel lainnya diasumsikan konstan atau sama dengan nol, maka average room rate akan meningkaat sebesar 0.009 .

Nilai koefisien regresi variabel komisi penjualan kamar (X2) sebesar 0.140 nilai yang positif menunjukan adanya hubungan searah antara average room rate dengan komisi penjualan kamar, jika komisi penjualan kamar meningkat sebesar satu satuan sementara variabel lainnya diasumsikan konstan atau sama dengan nol, maka average room rate akan meningkaat sebesar 0.140 . 
Hasil analisis Tabel 3 adalah hipotesis diterima jika nilai signifikansi $<0.05$. Nilai signifikansi $0.005<0.05$ ini berarti hipotesis pertama diterima, hal ini menunjukkan bahwa pendapatan kamar berpengaruh positif signifikan terhadap average room rate. Dari Tabel 3 diketahui nilai koefisien determinasi (Adjusted $R$ Square) adalah sebesar 0.406 atau sebesar $40.6 \%$ hal ini menunjukan bahwa pengaruh variabel independen yaitu Pendapatan kamar dan Komisi penjualan kamar adalah sebesar $40.6 \%$ terhadap variabel dependen yaitu average room rate dan sisanya 59.4 dipengaruhi oleh variabel lain yang tidak termasuk dalam model penelitian ini.

Hasil penelitian ini menunjukkan bahwa pendapatan kamar berpengaruh positif signifikan terhadap average room rate. Pengaruh biaya komisi penjualan terhadap average room rate. Hasil penelitian ini menunjukkan bahwa biaya komisi penjualan berpengaruh positif signifikan terhadap average room ratesehingga $\mathrm{H}_{2}$ diterima. Hal ini berarti bahwa apabila biaya komisi penjualan semakin meningkat maka average room rate juga akan meningkat.

nilai $\mathrm{F}$ hitung sebesar $27.953>\mathrm{F}$ tabel 3.12 dan niilai signifikansi $0.000<0.05$ maka hipotesis diterima. Hal ini berarti kedua variabel independen Pendapatan kamar dan Komisi penjualan kamar secara simultan berpengaruh signifikan terhadap variabel dependen yaitu average room rate.

Pengujian hipotesis 1 diterima jika nilai signifikansi $<0.05$. Nilai signifikansi $0.005<0.05$ ini berarti hipotesis pertama diterima, hal ini menunjukkan bahwa pendapatan kamar berpengaruh positif signifikan terhadap average room rate. Pengujian hipotesis 2 diterima jika nilai signifikansi $<0.05$. 
Nilai signifikansi $0.000<0.05$ ini berarti hipotesis pertama diterima, hal ini menunjukkan bahwa komisi penjualan berpengaruh positif signifikan terhadap average room rate.

Uji Parsial atau sering disebutUji-t digunakan untuk menguji secara parsial masing-masing variabel. Hasil uji-t dapat dilihat pada tabel coefficients pada kolom sig (significance). Jika probabilitas nilai $\mathrm{t}$ atau signifikansi $<0,05$, maka dapat dikatakan bahwa terdapat pengaruh antara variabel bebas terhadap variabel terikat secara parsial. Namun, jika probabilitas nilai $t$ atau signifikansi $>0,05$, maka dapat dikatakan bahwa tidak terdapat pengaruh yang signifikan antara masing-masing variabel bebas terhadap variabel terikat.

Nilai koefisien determinasi (Adjusted $R$ Square)adalah sebesar 0.406 atau sebesar $40.6 \%$ hal ini menunjukan bahwa pengaruh variabel independen yaitu Pendapatan kamar dan Komisi penjualan kamar adalah sebesar 40.6\% terhadap variabel dependen yaitu average room ratedan sisanya 59.4 dipengaruhi oleh variabel lain yang tidak termasuk dalam model penelitian ini.

Berdasarkan hasil penelitian ini, pendapatan kamar dan biaya komisi penjualan berpengaruh positif signifikan terhadap average room rate Hotel di Denpasar. Pendapatan kamar yang tinggi akan memberikan indikasi prospek perusahaan yang baik sehingga dapat memicu investor untuk ikut meningkatkan investasinya di bidang perhotelan daerah Denpasar. Di mana suatu perhotelan selain nilai pendapatan bersih perusahaan ada indicator penentu yaitu average room rate, sehingga penjualan rata-rata kamar di lihat dari average room ratenya sangat membantu pihak pemegang saham untuk mengatur strategi kepada pihak 
management hotel untuk menjaga stabilitas average room ratekamar tersebut. Biaya komisi penjualan yang tinggi akan memberikan indikasi dalam pemasaran melalui travel agent online lebih besar pengaruhnya terhadap average room rate saat ini dibandingkan dengan travel agent offline. Hal ini dapat memicu pihak pemasaran untuk meningkatkan penjualan di bidang online travel agent seperti halnya update fasilitas maupun kelengkapan hotel di media online.

Berdasarkan hasil penelitian ini menunjukkan bahwa penjualan kamar hotel saat ini lebih effisien dengan menggunakan online travel agent dibandingkan dengan offline travel agent. Dilihat dari besarnya komisi yang timbul dari hasil penjualan kamar tersebut juga berpengaruh terhadap meningkatnya average room rate kamar pada Hotel di Denpasar.

\section{SIMPULAN}

Hipotesis pertama menyatakan bahwa pendapatan kamar berpengaruh positif signifikan terhadap average room rate, sehingga $\mathrm{H}_{1}$ diterima. Karena pada penelitian ini pendapatan kamar berpengaruh terhadap average room rate pada hotel yang terdaftar di daerah Denpasar tahun 2017. Hipotesis kedua menyatakan bahwa biaya komisi penjualan berpengaruh positif signifikan terhadap average room rate, sehingga $\mathrm{H}_{2}$ diterima. Karena pada penelitian ini biaya komisi penjualan berpengaruh terhadap average room rate pada hotel yang terdaftar di daerah Denpasar tahun 2017

Bagi perusahaan, disarankan agar lebih meningkatkan pendapatan kamar melalui travel agent online karena meningkatkan pendapatan kamar dengan travel 
agent online juga dapat meningkatkan komisi penjualan terhadap average room rate hotel. Bagi peneliti selanjutnya agar tidak hanya menggunakan beberapa teori akuntansi perhotelan sebagai variabel yang mempengaruhi perusahaan, melainkan aspek lainnya dari akuntansi perhotelan seperti tingkat hunian kamar dan tingkat kepuasan pelanggan sebagai variabel tambahan dalam mempengaruhi average room rate hotel di Denpasar.

Bagi investor dapat menjadikan aspek keuangan sabagai alat ukur dan bahan pertimbangan untuk melakukan investasi agar dapat meminimalisir kerugian yang dialami saat mengambil keputusan berinvestasi di dunia perhotelan.

\section{REFERENSI}

Adekunle, A. (2014). Impact of Online Business on Operational Risk Management. Journal Of The Business School University of Gloucestershire. 6.

Bagyono, M. (2013). PenguasanOperasional Front Office di Hotel Bintang Lima. (PT. Gramedia), Jakarta.

Brian, A. (2014). Development of Tourism Object in South East Asia. PT. Gramedia. Pengaruh Motivasi Pada Minat Mahasiswa Non Akuntansi Untuk Mengikuti Pendidikan Profesi Akuntansi, Jakarta.

Campbell, K. (2015). Flexible Work Schedules, Virtual Booking Online, and Hotel Productivity. Journal of Walden Dissertations and Doctoral Studies., pp: 19.

Christanto, F. (2014). Analisis Penjualan Melalui Media Online Di Pt Wahana Travel Indonesia. Jurnal Program Manajemen Bisnis Universitas Petra.

Danny, A. (2013). Pengembangan Sumber Daya Manusia Pada Restoran Hotel City Of Tomorrow Surabaya. Jurnal Program ManajemenBisnis, . hal: 2.

Dunette, D. (2016). How To Increase Work Capability Based on Skill. PT. Era Intermedia : Jakarta. 
Fallon, E. (2015). Hotel and Resort Development Worldwide. PT. Inti Aksara: Surabaya.

Gehee, S. (2016). The Best Way to Gain More Hotel Revenue. PT. Java Books : Jakarta.

Gordon, M. (2016). Skill and Workhard Scale to Indicate The Hotel Productivity. PT. Gramedia: Jakarta. Retrieved from http://kiss.kstudy.com/search/detail_page.asp?key=3165102

Sihite. (2010). Operasional Hotel dan Pengembangannya. PT. Kompas : Jakarta. Retrieved from http://kiss.kstudy.com/search/detail_page.asp?key=3165102

Vallen, F. (2015). Front Office Procedure on Luxury Hotel. PT. Putra Pertama: Surabaya.

Wild, F. (2013). An Examination of Satisfaction of Hotel Management According to Extrinsic, Intrinsic, and General Motivational Factors. International Journal of Business and Social Science, pp: 02.

Yee, C. S. (2013). The Effect Of Digital Booking By Organization Towards Productivity In Hotel Industry. A Research Project of Bachelor Of Business Administration, 16, pp: 23. 